\title{
УАК 343.85
}

ИеоніА Віталійович Бокаріус, кандидат медичних наук, онук Засл. професора М. С. Бокаріуса, США

Сергій Віталійович Бокаріус, онук Засл. професора М. С. Бокаріуса, США

Наталія Свгенівна Філіпенко, кандидат юридичних наук, доцент, Аоцент кафедри права гуманітарно-правового факультету

Національного аерокосмічного університету ім. М. Є. Жуковського

«Харківський авіаційний інститут», м. Харків, Україна

ORCID: https://orcid.org/0000-0001-9469-3650

e-mail: filipenko_natalia@ukr.net

\section{Медицина - професія їхньої долі}

\section{Династія - че горде слово! \\ Сплелися покоління в ньому.}

Постановка проблеми. Коли ми кажемо "трудова династія", перед очима мимоволі постають картини сивої давнини, але "династія" - це феномен, що динамічно розвивається, та який увібрав у себе як минуле й сьогодення, так і майбутнє.

Словосполучення "трудова династія" містить у собі глибокий сенс, велич років, відданість обраній професії, сімейні традиції та надзвичайну відповідальність за вчинки прийдешніх поколінь. Адже немає нічого кращого, коли діти й онуки мріють бути гідними своїх батьків, коли слова "хочу продовжити твою справу" звучать як найвища пошана до досягнень пращурів! Династія - це безперервний ряд поколінь, які передають із роду в рід професійну майстерність і найкращі сімейні традиції.

У минулому династію називали за іменем її родоначальника або видатного представника. Саме про таку шляхетну династію медиків йдеться, адже допомагати людям - надзвичайно благородна справа. Образ медика в уяві багатьох пов'язаний із надією на життя та здоров'я, захистом від болю й біди. Кажуть, що лікар - це посередник між людиною і Богом. Медик лікує не лише тіло, а й душу пацієнта, уселяючи в його серце віру в краще майбутнє. Це всесвітньо відома сім'я, родоначальником якої є видатний науковець, судовий медик, гуманіст та просвітник М. С. Бокаріус. Його науково-практична діяльність увійшла до історії вітчизняної медичної, судово-експертної та криміналістичної думки помітною сторінкою, його праці та практичний доробок як судового медика значно вплинули на практичну діяльність експертів, збагатили наукову школу України новими положеннями і думками.

Без перебільшення можна стверджувати, що Микола Сергійович є засновником не однієї династії, а двох. Перша - наукова спільнота судових медиків, людей, які з покоління в покоління гідно підтримують принципи наукової діяльності, закладені ще в 1925 році, коли було створено Харківський науково-дослідний інститут судових експертиз. Саме професор долучився до створення наукової еліти судових медиків, адже під його безпосереднім керівництвом в інституті було виконано понад 50 науково-дослідних робіт. У 1925 році, ураховуючи плідну наукову, педагогічну й організаційну діяльність М. С. Бокаріуса в галузі судової медицини та криміналістики, йому було присвоєно почесне звання "Заслужений професор". Власне завдяки беззаперечному науковому і пе-

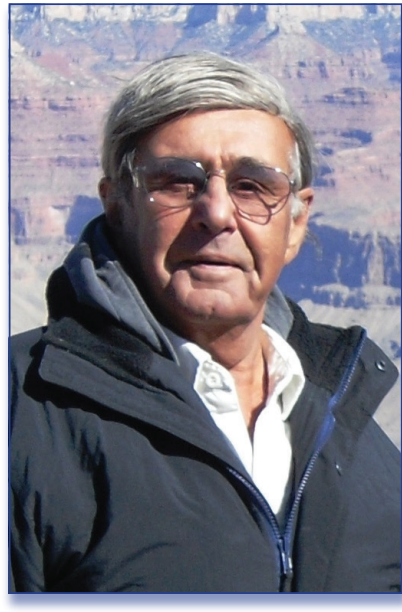

Бокаріус

Меонід Вітамійович

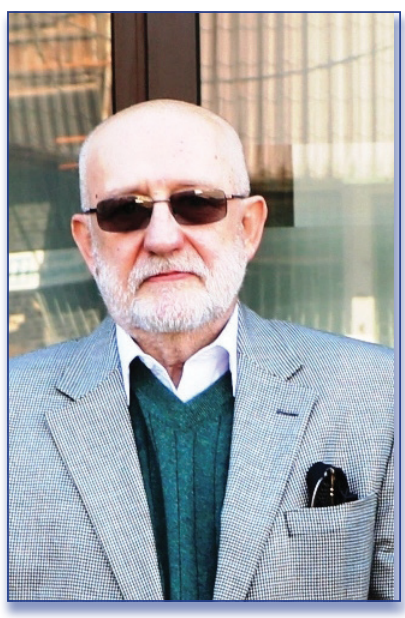

Бокаріус

Сергій Вітамійович

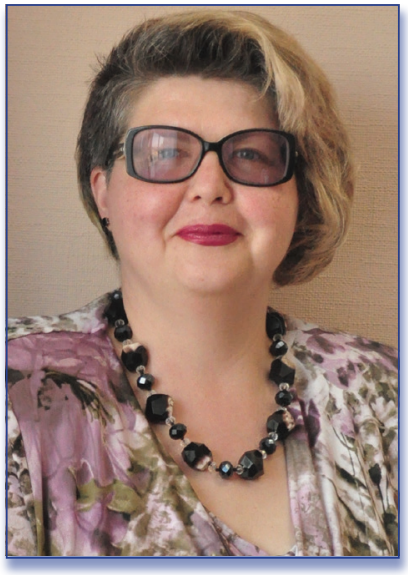

Філіпенко

Натанія Євгенівна 
$\Lambda$. В. Бокаріус, С. В. Бокаріус, Н. Є. Фіміпенко

МЕАИЦИНА - ПРОФЕСІЯ ÏХНЬОЇ $\Delta \mathrm{O} \Lambda \mathrm{I}$

Словосполучення «трудова Аинастія» містить у собі глибокий сенс, велич років, віАданість обраній професії, сімейні траАиції та надзвичайну відповіАальність за вчинки прийдешніх покомінь. Аинастія - це безперервний ряА поколінь, які переАають із роду в ріА професійну майстерність і найкращі сімейн традиції. У минулому Аинастію називали за іменем іiі родоначамьника або виАатного преАставника. Саме про таку шляхетну Аинастію медиків йдеться. Це всесвітньо відома сім'я, родонача ьником якої є видатний науковець, судовий медик, гуманіст та просвітник М. С. Бокаріус. Без перебільшення можна стверджувати, що Микола Сергійович є засновником не однієї Аинастії а двох. Перша - наукова спільнота судових меАиків, АюАей, які 3 покоління в покоління гіАно піАтримують принципи наукової Аіяльності, закладені ще в 1925 році, коли було створено Харківський науково-Аос $\Lambda$ інний інститут судових експертиз. Але Микола Сергійович залишив

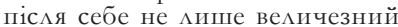
науковий доробок i тисячі учнів та посліАовників. МожАиво, найголовнішим його спаАком $є$ заснування сімейної справи, де кожен із нащадків вимірює своє життя за суворими критеріями трудової Аинастії Бокаріусів.

Першим із роду був виАатний судовий експерт, вихователь плеяли судових меАиків і криміналістів Микола Миколайович Бокаріус. ГіАно продовжила справу батька й Кіра Миколаївна Бокаріус - онука Миколи Сергійовича.

Молодшим сином М. С. Бокаpiуса був Віталій Миколайович Бокаріус - знаний науковець, шанований судовий експерт, праці якого й Аосі користуються популярністю сереА студентів та вик адачів. Авом своїм синам, Меоніну Віталійовичу та Сергію Віталійовичу Бокаріусам, він передав потяг до знань, повагу Ао професії та самовідаане служіння ілеалам добра та честі.

П'ять поколінь меАичної Аинастії Бокаріусів і нині служать АюАям, віААаючи щирість своєї Ауші, чуйність серця на благо суспільства. Усім представникам цієї Аинастії $\epsilon$ чим пишатися, аАже вони дбайливо зберігають традиції,

дагогічному авторитету Миколи Сергійовича, харківська школа судових медиків вийшла на світовий рівень, стала знаною та поважною серед наукової спільноти багатьох країн. І сьогодні, майже через 100 років після заснування, науковці інституту працюють за завітами великого наставника, гідно збагачуючи світ знань та втілюючи в життя принципи гуманізму М. С. Бокаріуса задля процвітання України.

Але Микола Сергійович залишив після себе не лише величезний науковий доробок і тисячі учнів та послідовників. Можливо, найголовнішим його спадком є заснування сімейної справи, де кожен із нащадків вимірює своє життя за суворими критеріями трудової династії Бокаріусів. Ця родина є взірцем працьовитості, цілеспрямованості, честі та беззастережного служіння людям.

Аналіз публікацій, у яких започатковано висвітлення даної проблеми. Видатне життя й діяльність представників династії Бокаріусів були предметом наукових праць та розгляду багатьох вітчизняних науковців, зокрема О. М. Клюєва, В. О. Ольховського, Ж. М. Перцевої, Е. Б. Сімакової-Єфремян,

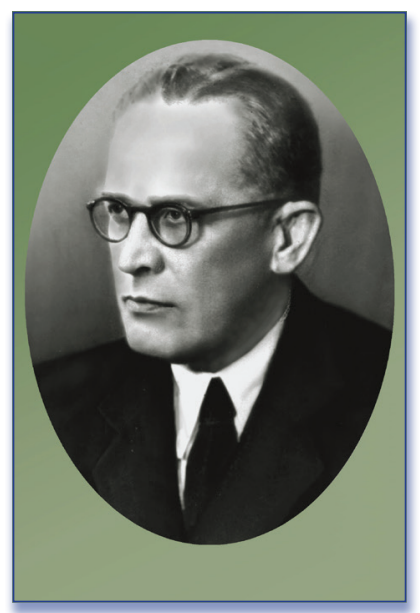

Микола Миколайович Бокаріус (1899-1966)
О. П. Угровецького, В. Ю. Шепітько ${ }^{1}$ та інших. Але окремі факти в біографіях молодших представників цієї знаної родини розглядалися недостатньо. Тому, грунтуючись на спогадах онуків M. С. Бокаріуса та прийомної доньки Віталія Миколайовича, Марини Віталіївни Бокаріус, у статті зроблено спробу заповнити ці прогалини та визначити роль інших представників родини в розвитку не лише вітчизняної, а й міжнародної медичної і судово-експертної думки.

Мета даної публікації - заповнити прогалини в історії життя та діяльності багатьох поколінь судових медиків Бокаріусів.

Виклад основного матеріалу. Одним 3 перших із роду був видатний судовий експерт, вихователь плеяди судових медиків і криміналістів Микола Миколайович Бокаріус.

У 1917 році із відзнакою закінчив гімназію та вступив на медичний факультет Харківського університету. Після його закінчення працював асистентом на кафедрі судової експертизи Харківського медичного інституту (XMI). У 1924 році завідував секцією ідентифікації, а пізніше секцією судово-біологічних досліджень у Харківському інституті науково-судової експертизи. Водночас М. М. Бокаріус очолює кафедри медицини в 1-му та 2-му ХMI, Українському інституті удосконалення лікарів, викладає в цих вишах. У 1931 році йому присвоєно вчене звання "професор". Під його керівництвом виконано понад 30 дисертаційних робіт (серед них - 4 докторські дисертації).

Із 1933 по 1937 роки М. М. Бокаріус працював Республіканським судово-медичним експертом і керівником Харківського обласного бюро судово-медичної експертизи, був головою Всесоюзного та Республіканського товариств судових медиків і криміналістів, членом редакційної ради журналу "Судово-медична експертиза".

\footnotetext{
Ао 150-річчя з дня народження Заслуженого професора Миколи Сергійовича Бокаріуса : монографія / О. М. КАюєв, О. П. Угровецький, Е. Б. Сімакова-Єфремян та ін. // Передм. О. М. КАюєва. Харків : ХНІАСЕ ; Промінь, 2019. 176 с. $з$ іл.
} 


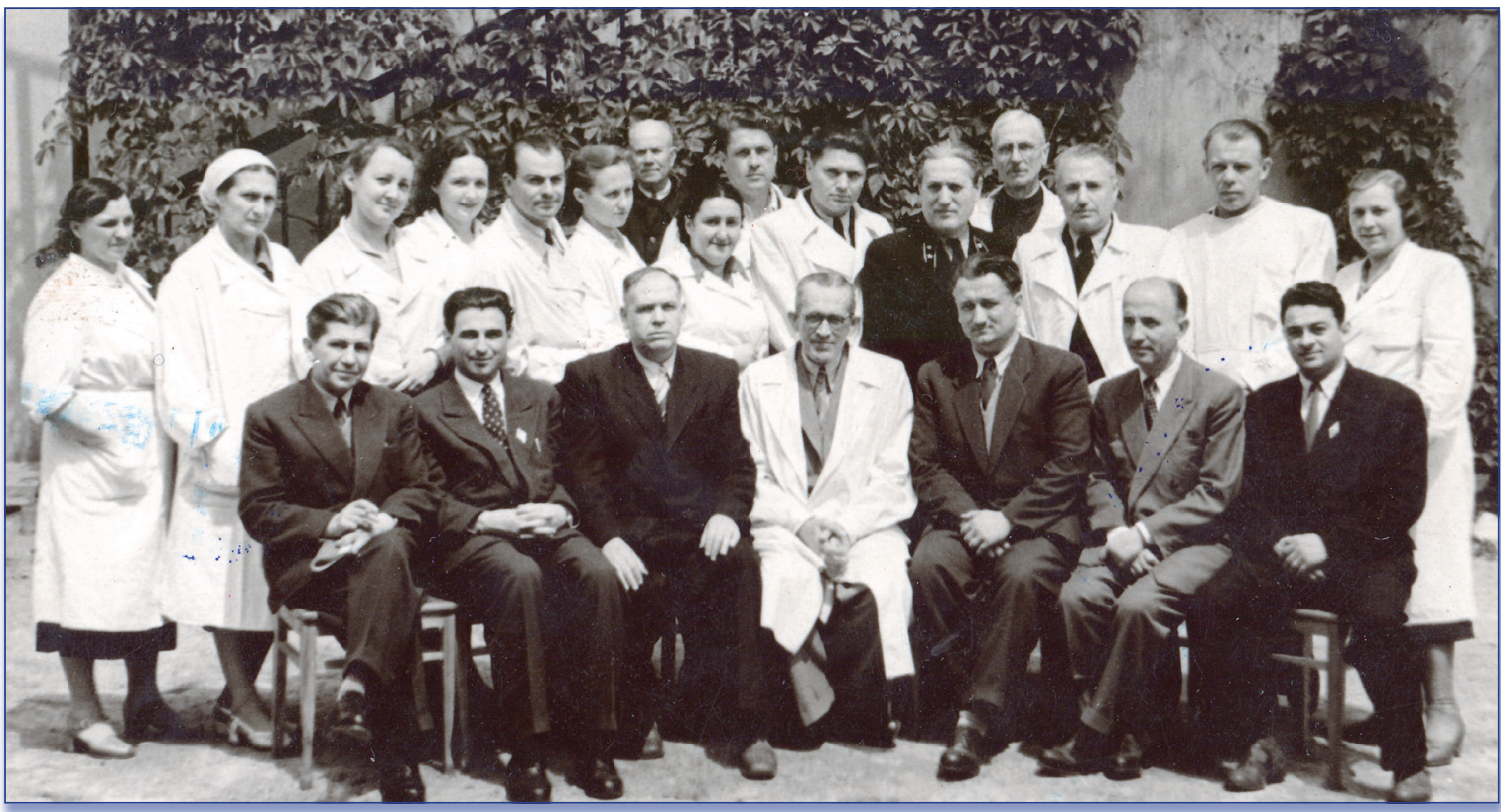

М. М. Бокаріус (по центру) із судовими меАиками та кримінахістами з Румунії, 1956 р. (світмина публікуеться вперше)

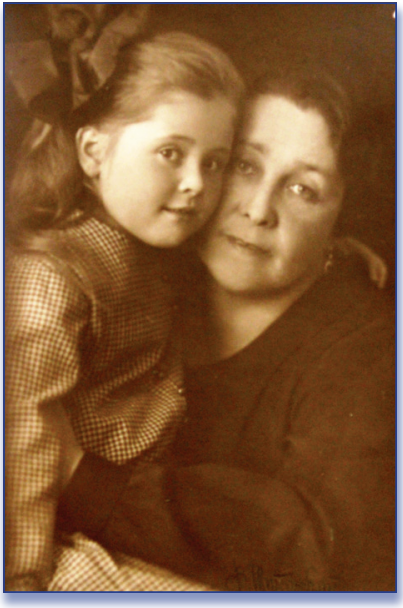

К. М. Бокаріус із бабусею (світмина пубцікусться вперше)
M. M. Бокаріус очолював інститут судових експертиз у дуже складний період його діяльності - роки Другої світової війни (вересень 1939 - вересень 1945) і окупації м. Харків (жовтень 1941 - серпень 1943). Саме він, після смерті батька, зумів не лише зберегти, а й розширити інститут судових експертиз, плекаючи кожного працівника, як члена власної родини, оберігаючи науку від популізму і знищення. Власне завдяки зусиллям Миколи Миколайовича, харківська школа судових медиків посилила свій вплив на наукову думку закордонних учених, чимало з яких уважали себе учнями українських медиків ${ }^{2}$.

Гідно продовжила справу батька й Kipa Миколаївна Бокаріус - онука Миколи Сергійовича.

У 1938 вона вступила до 1-го Харківського медичного інституту, який закінчила в 1942 році. Ще дівчинкою вона пішла захищати Батьківщину на фронтах Другої світової війни, очолюючи польовий шпиталь, рятуючи життя воїнів та повертаючи їм віру в життя не лише скальпелем, а й мудрим, душевним словом.

У 1946 році Кіра Миколаївна вступила до аспірантури на кафедру судової медицини Харківського медичного інституту. Після закінчення аспірантури була прийнята на роботу в Харківський НДІ судових експертиз ім. Засл. проф. М. С. Бокаріуса старшим науковим

Спогади С. В. Бокаріус про батька - В. М. Бокаріус. Рукопис. передають із покоління в покоління АосвіА, знання і майстерність, будучи в сучасному світі унікацьним ресурсом і $ю$ юським капітацом, транслюючи досвіА, знання та родинні цінності. Медицина це професія їхньої Аолі!

КАючові слова: Заслужений професор М. С. Бокаріус, Аинастія, Микола Миколайович Бокаpiуc, Віталій Миколайович Бока piуc, життєвий шАях, меАична наукова Аіяльність, судова експертиза і криміналістика.

L. Bokarius, S. Bocarius,

N. Filipenko

MEDICINE IS THE

PROFESSION OF THEIR DESTINY

The complex process of deThe phrase "labor dynasty" has a deep meaning, greatness of years, devotion to the chosen profession, family traditions, and extraordinary responsibility for the actions of future generations. A dynasty is a continuous series of generations that pass on professional skills from family to family and the best family traditions. In the past, the dynasty was named after its ancestor or prominent representative. It is about such a noble dynasty of physicians. This is a world-famous family which ancestor is M. S. Bokarius, prominent scientist, forensic medical examiner, humanist and 
educator. It is no exaggeration to say that Mykola Mykolayovych founded not one dynasty, but two. The first is the scientific community of forensic medical examiners, people who from generation to generation worthily support the principles of scientific activity, laid down in 1925, when Hon. Prof. M. S. Bokarius Kharkiv Research Institute of Forensic Examinations was established. However, Mykola Serhiyovych left behind not only a huge scientific achievement and thousands of students and followers. Perhaps his most important legacy is the establishment of a family business, where each of the descendants measures their lives according to the strict criteria of the Bokarius dynasty.

Mykola Mykolayovych Bokarius was the first of his family was an outstanding forensic expert, educator of a constellation of forensic medical examiners and criminalists. Kira Mykolaivna Bokarius, Mykola Mykolayovych granddaughter, continued the father's work with dignity.

The youngest son of M. S. Bokarius was Vitaliy Mykolayovych Bokarius, well known scientist, respected forensic medical examiner whose works are still popular among students and teachers. He passed on to his two sons, Leonid and Sergei, a desire for knowledge, respect for the profession and selfless service to the ideals of goodness and honor.

Five generations of Bokarius medical dynasty still serve the people, giving sincerity of their souls, sensitivity of heart for the benefit of society. They all have something to be proud of, because they carefully preserve traditions, pass on from generation to generation experience, knowledge and skills, being a unique resource and human capital in the modern world, transmitting experience, knowledge and family values. Medicine is the profession of their destiny!

Keywords: M. S. Bokarius, professor emeritus, dynasty, Mykola Mykolayovych Bokarius, Vitaliy Mykolayovych Bokarius, way of living, medical and scientific activity, forensic science and criminalistics. співробітником. За цей період нею було підготовлено понад 40 науководослідних робіт.

На жаль, у Кіри Миколаївни не було власних дітей, а прийомна донька також рано пішла із життя, не залишивши спадкоємця. Здавалося б,

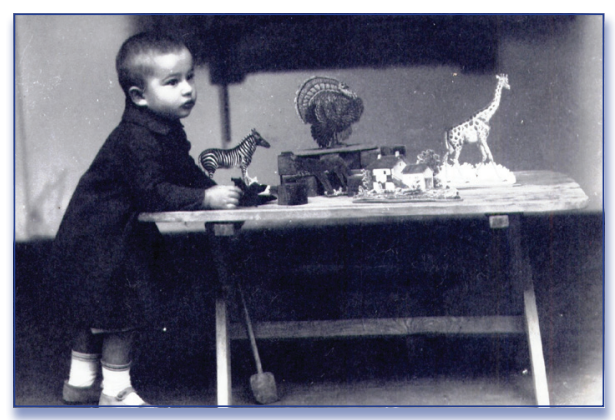

Віталій Бокаріус (світлина публікуеться вперше) славетна династія може завершитися. Та надія завжди є.

У 1921 році (через 22 роки після народження Миколи Миколайовича) у Миколи Сергійовича та Ніни Марківни, другої дружини Миколи Сергійовича, народився довгожданий син - Віталій Миколайович Бокаріус. А в січні 1923 донька Флоренція.

На жаль, батько недовго тішився нащадками, передчасно померши. Проте дружні, приязні родинні стосунки

не перервалися. Між братами (Миколою Миколайовичем та ВіталіємМиколайовичем Бокаріусами) завжди зберігалася теплота відносин і повага один до одного. Микола Миколайович досить часто навідувався до брата в Ленінград, де той мешкав після війни (Віталій називав свого старшого брата Миколою Миколайовичем, адже давалася взнаки значна різниця у віці, але звертався на "ти").

у гостинному домі Віталія Миколайовича часто бували цікаві люди: викладачі Військово-Медичної академії, Ленінградського Державного інституту удосконалення лікарів, судово-медичні експерти та криміналісти, які приїжджали до Ленінграда, Кіра Миколаївна із чоловіком Юрієм Яковлєвим, відомим фізиком. Бували фронтові й харківські

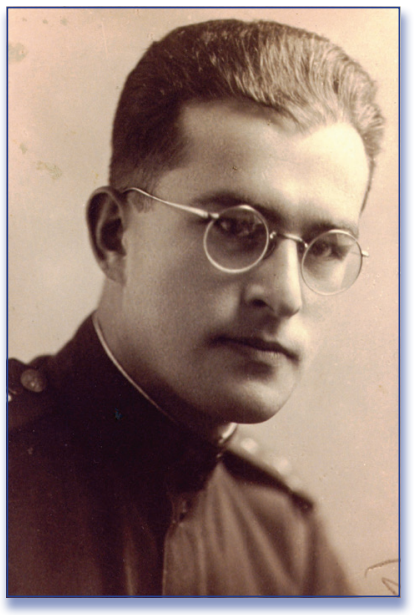

Віталій Миколайович Бокаріус (1921-1969 pp.) друзі Віталія Миколайовича: харків'янин М. І. Відрє (гастроентеролог), М. Я. Лапінер (кардіолог), судово-медичні експерти С. Д. Кустанович, Дм. Джемс-Леви, А. Р. Деньковський (очільник кафедри судової медицини Військово-медичної Академії), В. Ю. Готьє, син видатного історика та інші. На цих зустрічах завжди було весело, співали фронтових пісень, романси, танцювали під патефон, грали на піаніно, читали вірші, сперечалися щодо найрізноманітніших речей. Віталій Миколайович був "душею компанії", навіть умів показувати фокуси, чим дуже тішив своїх дітей (на їхні дні народження влаштовував костюмовані вистави). Попри величезну зайнятість, Віталій Миколайович чимало часу проводив із дітьми. Особливим святом для них були походи до цирку (тоді його називали по-старому - "цирк Чинізеллі"), де вони із задоволенням дивилися на чудового клоуна Бориса Вяткіна із собачкою за кличкою "Манюня", зачаровувалися фокусами Еміля Кіо. 
Віталій Миколайович багато працював, вихідний був лише один неділя. Тоді родина ходила в гості, до театру та філармонії. А коли діти залишалися на самоті, то весело проводили час із сусідськими дітьми. Телевізор був надзвичайною рідкістю. У комунальній квартирі, де мешкав В. М. Бокаріус із сім'єю, телевізор був один на всі чотири сусідські родини - "КВН» із великою лінзою, заповненою водою, адже екран був розміром приблизно, як чотири сірникові коробки. Також у родині був маленький проєктор для перегляду діапозитивних фільмів; старші читали титри, молодші, затамувавши подих, слухали, грали в "Чудо-вогник" (грувікторину, яку цінували за її пізнавальність).

Бував у родинному колі на Таврійській вулиці й відомий кіносценарист i поет О. Галич, друг московської юності мами Сергія, співав своїх пісень...

Як згадують сини Віталія Миколайовича, це був час, коли дефіцитом було ВСЕ! Але на столі завжди була найпростіша і смачна їжа: вінегрет з оселедцем, ще якісь салати, квашена капуста, варена картопля, солоні огірки і помідори, домашні мариновані гриби і, звичайно, дуже смачний чорний хліб. За справжнім білим хлібом Сергій бігав до булочної перед школою до його відкриття. Віталію Миколайовичу, після першої операції у 1959 році, потрібен був саме такий хліб, який "по блату" залишала знайома завідувачка булочної, видаючи хліб із "чорного" входу. На Новий рік шумно відкорковувалися пляшки шампанського. Як же вони веселилися - 40-річні ветерани страшної війни! I нікому не було затісно у двох кімнатах комунальної квартири, де тоді мешкала родина. Святковий стіл завжди був заставлений найсмачнішими наїдками, i Віталій Миколайович часто жартома казав про дружину: “... нашій мамі потрібно працювати диспетчером по пересадці $з$ одного космічного супутника на інший", адже все "горіло" в її вправних руках .

Друга дружина Віталія Миколайовича, Феліка Михайлівна БокаріусРапопорт, лікар, закінчила 1-й московський медичний інститут ім. І. М. Сєченова в 1939 році, працювала в Кабардино-Балкарії в місті Мікоян-Шахар (нині - Карачаєвськ).

Під час війни працювала завідувачкою сільської лікарні в селі Ширяєве Жигулівського району під Куйбишевом (нині - Самара). Її дільниця охоплювала досить значну територію, і Феліка Михайлівна змушена була добиратися до хворих верхи, саньми, човном по Волзі... У квітні 1944 вона повернулася до Москви і служила у Військовоюридичній Академії старшим лаборантом на кафедрі криміналістики і судової медицини, якою завідував М. І. Авдєєв, де в 1945 році познайомилася з Віталієм Миколайовичем, коли той приїхав з фронту на курси з удосконалення судових медиків. У червні 1947 вони одружилися і Віталій Миколайович удочерив Марину, доньку Феліки Михайлівни від першого шлюбу, яка народилася в травні 1941 року, за місяць до початку
L. Bokarius, S. Bocarius, N. Filipenko

\section{MEDIZIN IST DER BERUF} IHRES SCHICKSALS 
die Tausenden von Studenten und Anhängern. Die Gründung eines Familienunternehmens, in dem jeder der Nachkommen sein Leben nach den strengen Kriterien der Bokarius-Dynastie misst, ist vielleicht sein wichtigstes Erbe.

Der erste von der Generation war ein hervorragender Forensiker, der Pädagoge von Sterngerichtsmedizinern und Kriminalisten Mykola Mykolayovych Bokarius. Kira Bokarius, die Enkelin von Mykola Bokarius, setzte die Arbeit ihres Vaters auch mit Würde fort.

Der jüngste Sohn von Mykola Bokarius war Vitaliy Bokarius, ein bekannter Wissenschaftler, angesehener Forensiker, dessen Werke bei Schülern und Lehrern immer noch beliebt sind. Er vermittelte seinen beiden Söhnen Leonid und Sergei Bokarius Verlangen nach Wissen, Respekt vor dem Beruf und selbstlosen Dienst an den Idealen von Güte und Ehre.

Fünf Generationen der medizinischen Dynastie von Bokarius dienen immer noch den Menschen und geben die Aufrichtigkeit ihrer Seele, die Sensibilität des Herzens zum Wohle der Gesellschaft. Sie alle haben etwas, auf das sie stolz sein können, denn sie bewahren die Traditionen sorgfältig, geben von Generation zu Generation Erfahrung, Wissen und Fähigkeiten weiter, sind die einzigartige Ressource und das Humankapital in der modernen Welt und vermitteln die Erfahrung, das Wissen und die Familienwerte. Medizin ist der Beruf ihres Schicksals!

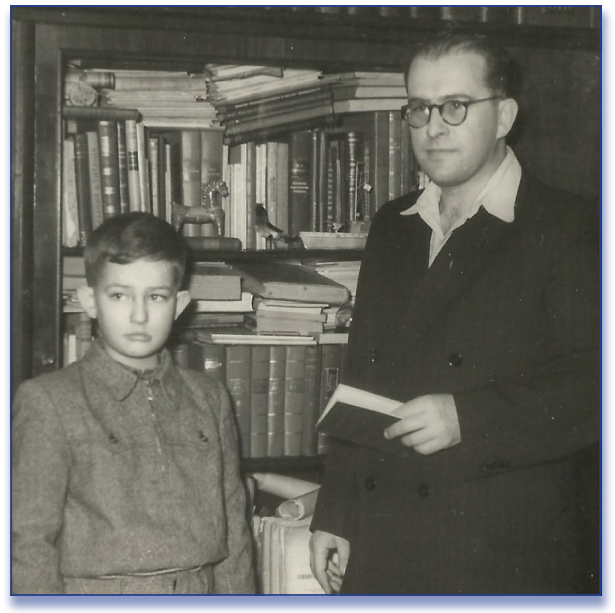

Віталій Миколайович Бокаріус із сином Сергієм (світАина публікуеться вперше)

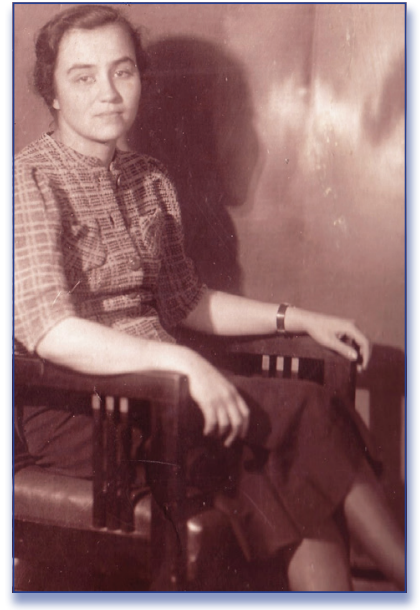

Ф. М. Бокаріус-Рапопорт (світлина публікуеться вперше)

№ 11 лікарем-лаборантом. Але найвища кваліфікація дозволяла їй протягом тривалого часу надавати фахові консультації значній кількості працівників різних медичних установ. Ця прекрасна жінка працювала все своє свідоме життя, пішовши на пенсію в 75 років!

Це була дружна родина, у якій панували взаємоповага та любов. Подружжя Бокаріусів прожило разом понад 20 років, і жодного разу вони не сварилися, говорячи один з одним на "підвищених" тонах. Віталій Миколайович був безмірно витриманим. Він не дозволяв собі, навіть в екстремальних ситуаціях, посилювати голос, ніколи не промовляючи лайливих слів. Він говорив, що протягом усієї війни жоден старшина не зміг змусити його вилаятися!

Дружні стосунки пов'язували Віталія Миколайовича 3 відомим хірургом, академіком, віце-президентом Академії медичних наук СРСР, генерал-лейтенантом медичної служби Петром Андрійовичем Купріяновим - начальником кафедри факультетської хірургії № 2, якого він безмежно шанував. Віталій Миколайович розповідав, що клініка професора Купріянова - єдина в академії, де вночі сестри не сплять, тому що П. А. Купріянов міг несподівано приїхати серед ночі відвідати тяжкохворого. А наявність пилу професор перевіряв своєю білосніжною хустинкою. Персонал поважав його і порядок у клініці був бездоганним.

Віталій Миколайович, як і його батько, був пристрасним філателістом, продовжуючи збирати марки та поповнюючи родинний альбоми "Schaubek", який дивом уцілів під час війни. Завдяки цьому захопленню, Віталій Миколайович познайомився 3 генерал-лейтенантом медичної служби, заступником начальника ВMA 3 науки, професором О. С. Георгієвським, чудовим офіцером, який на усіх парадах очолював "коробку" військових лікарів-офіцерів... Микола Сергійович Бокаріус майстерно володів олівцем, прекрасно писав маслом і аквареллю. Деякі його картини "пережили" окупацію Харкова й висіли у квартирі на вулиці Чернишевська, 46 у його сина, Миколи Миколайовича 
Бокаріуса. Онукам Миколи Сергійовича вони здавалися величезними, "як у Ермітажі». У Сергія Віталійовича Бокаріуса, онука Миколи Сергійовича, який зараз мешкає в СанФранциско, є три написані Миколою Сергійовичем картини. На одній картині море зображено таким прозорим і добрим, що здається живим; на другій - воно нічне, із темним силуетом кораблика. Саме ця картина нагадує роботи Куїнджі.

Віталій Миколайович, як і його батько, малював скрізь, коли була вільна хвилина (навіть на фронті). Чимало його малюнків збереглося і знаходяться зараз у Сан-Франциско. Віталій Миколайович, як і Микола Сергійович, дуже любив писати море, пейзажі. Його етюдник завжди подорожував із ним. Будучи студентом, він підробляв: робив креслення і малюнки, навчальні посібники і таблиці для занять на кафедрі, був чудовим оформлювачем.

Віталій Миколайович повністю віддавався науці та користувався заслуженим авторитетом серед колег. У 1947 році він, у складі групи експертів, виїжджав на місце дуелі М. Ю. Лермонтова. Вони проводили судовомедичну та балістичну експертизи. У вересні 1948 року Віталій Миколайович брав участь в обстеженні бальзамованого тіла М. І. Пирогова в маєтку "Вишня", тому що під час війни мародер зламав саркофаг і вкрав хрест із дорогоцінними каменями, полишений у руках М. І. Пирогова. До від’їзду із СРСР Сергій Віталійович підтримував стосунки з музейними співробітниками, побувавши у "Вишні" (січень 1982) i передавши їм деякі матеріали з архіву Віталія Миколайовича, яких не вистачало в експозиції.

У родині зберігалося чимало книжок із особистої бібліотеки Миколи Сергійовича. Кілька десятків словників (зокрема словник циганської мови), 8 томів великої французької енциклопедії "LAROUSSE" $з$ прекрасними ілюстраціями, безліч підручників та інших цікавих книг: праці Миколи Сергійовича і Ніни Марківни, яка теж була лікарем (закінчивши медичну школу в Сорбонні працювала прозектором на кафедрі в Миколи Сергійовича); альбоми з марками тощо. Зберігала родина й ікони Миколи Сергійовича в срібних окладах, які в 1958 році Віталій Миколайович подарував Храму Усікновення Глави Іоанна Предтечі, прихожанином якого був Микола Сергійович, i поруч з яким тоді була його могила...

Віталій Миколайович вільно спілкувався французькою, німецькою та англійською мовами, знав італійську, іспанську та, звісно, латинь. Коли в 1960 році до Ленінградського державного інституту удосконалення лікарів приїхав італійський професор Д. Петруччі, який вивчав питання "Гомункулуса", В. М. Бокаріус синхронно перекладав його лекцію із французької, тому що в місті не знайшлося більш досвідченого перекладача-фахівця високого рівня.

Окрім енциклопедичних знань, Віталій Миколайович мав чудову фантазію і дар викладання. Його хотілося слухати! Присутні, особливо студенти, були "закохані" у викладацький талант В. М. Бокаріуса. Він також викладав судову медицину на юридичному факультеті Ленінградського державного університету.

Помер Віталій Миколайович 10 січня 1969 року після тривалої невиліковної хвороби. Йому було лише 47 років... Протягом усіх цих дуже складних 10 років хвороби поряд із Віталієм Миколайовичем була його дружина і друг - Ф. М. Бокаріус.

Schlüsselwörter: Ehrenprofessor M. Bokarius, Dynastie, Mykola Bokarius, Vitaliy Bokarius, Lebensweg, medizinische und wissenschaftliche Tätigkeit, Forensik und Kriminalistik.

L. Bokarius, S. Bocarius,

N. Filipenko

ANALYSE DE LA SITUATION

MÉDECINE EST LA

PROFESSION DE LEUR DESTIN

Le processus complexe La locution « dynastie ouvrière » contient un sens profond, la grandeur des années, le dévouement à la profession choisie, les traditions familiales et une responsabilité extraordinaire pour les actions des générations futures. Une dynastie est une série continue de générations qui transmettent de lignée en lignée les compétences professionnelles et les meilleures traditions familiales. Dans le passé, la dynastie portait le nom de son ancêtre ou de son représentant éminent. Il s'agit d'une telle noble dynastie de médecins. C'est une famille de renommée mondiale. Son ancêtre est M. S Bokarius est un éminent scientifique, médecin légiste, humaniste et éducateur. Il n'est pas exagéré de dire que Mykola Serhiyovych est le fondateur non pas d'une seule dynastie, mais de deux. La première est la communauté scientifique des médecins légistes, 
des personnes qui de génération en génération soutiennent dignement les principes de l'activité scientifique, établis en 1925 lors de la création de l'Institut de recherche d'expertise judiciaire de Kharkiv. Pourtant, Mykola Serhiyovych a laissé non seulement une énorme réussite scientifique et des milliers d'étudiants et d'adeptes. Peut-être, son héritage le plus important est la création d'une entreprise familiale, où chacun des descendants mesure sa vie selon les critères stricts de la «dynastie ouvrière » des Bokarius.

Le premier descendant de la famille était Mykola Mykolayovych Bokarius, un expert judiciaire exceptionnel, éducateur d'une constellation de médecins légistes et criminalistes. Kira Mykolaivn Bokarius, petite-fille de Mykola Serhiyovych, a également poursuivi l'œuvre de son père avec dignité.

Le fils cadet de M. S. Bokarius était Vitaliy Mykolayovych Bokarius, un scientifique bien respecté, dont les travaux sont toujours populaires parmi les étudiants et les enseignants. Il a transmis un désir de connaissance, de respect de la profession et de service sacrifié aux idéaux de bonté et d'honneur à ses deux fils, à Leonid et à Sergei. connu, un expert judiciaire

Але зі смертю В. М. Бокаріуса велика лікарська династія не зникла. Естафету перейняли його сини - Леонід Віталійович та Сергій Віталійович Бокаріуси.

Леонід Віталійович Бокаріус народився в Харкові в 1944 році.

Його мати - Есфір Лазарівна Туніна. У медінституті вони вчилися

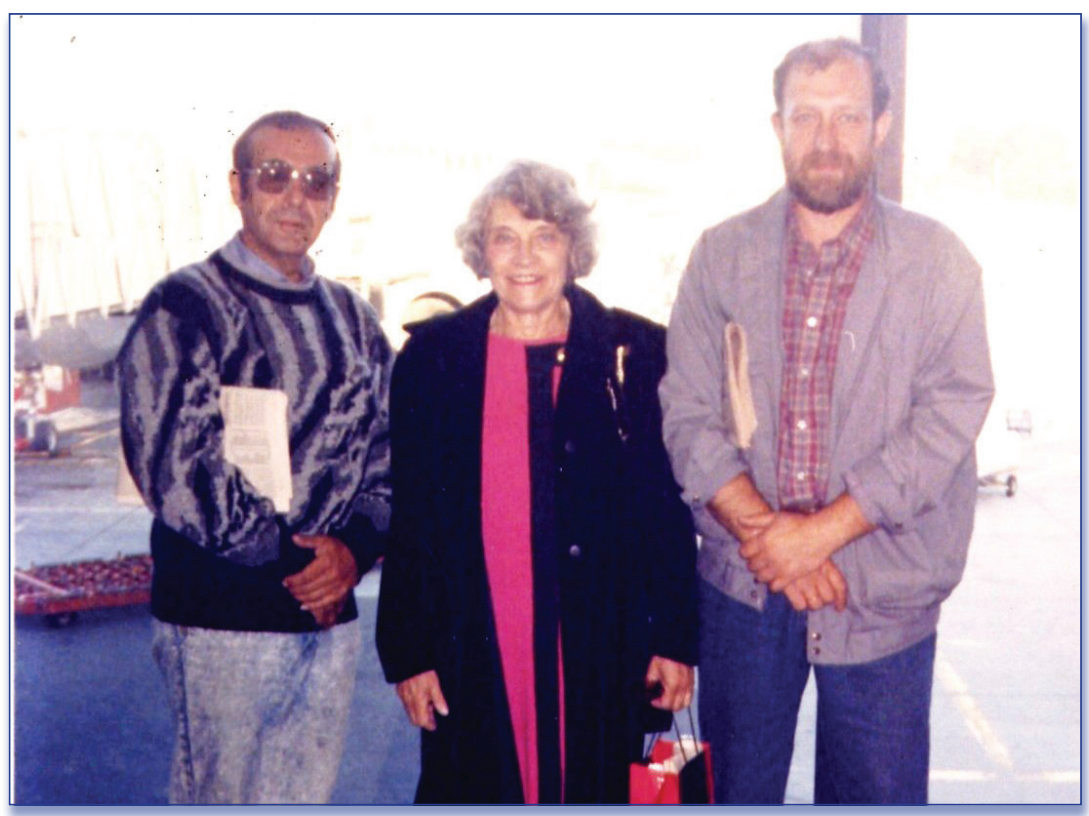

ФАоренція Миколаївна Бокаріус - донька М. С. Бокаріуса (по центру) та онуки професора $-\Lambda$ еоніА Віталійович (Аіворуч) та Сергій Віталійович Бокаріус (праворуч). Сан-Франциско, 1990 р.

разом 3 Віталієм Миколайовичем. Із інститутом були евакуйовані до Чкалова (нині - Оренбург), де й закінчили навчання, одружилися і були направлені до фронтових шпиталів. До відправки на фронт Віталій Миколайович був молодшим лікарем у Запасному полку ПТР (протитанкових рушниць). Після остаточного визволення Харкова Есфір Лазарівна була демобілізована у зв'язку з вагітністю. Надалі вона понад 40 років працювала в Харківському бюро судово-медичної експертизи. У 1949 році відмінно захистила дисертацію й отримала вчене звання кандидата медичних наук. Есфір Лазарівна Туніна була одним із кращих вітчизняних фахівців у сфері судово-медичного огляду живих осіб. Окрім того, протягом багатьох років викладала судову медицину на кафедрі криміналістики Харківського юридичного інституту.

Cing générations de la dynastie médicale des Bokarius sont toujours au service du peuple donnant la sincérité de son âme, la sensibilité du cœur au profit de la société. Ils ont tous de quoi être fiers, car ils préservent soigneusement les traditions,
Саме тоді батько, Віталій Миколайович, продовжував служити в діючій армії. На жаль, батьки Леоніда Віталійовича розлучилися незабаром після його народження. Леонід, формально, був усиновлений другим чоловіком Есфірі Лазарівни - Давидом Зіновійовичем Стругацьким, і до того, як пішов у школу, мав прізвище вітчима - Стругацький . На початку 50-х років минулого сторіччя в СРСР розпочався страшний період "державного антисемітизму", і родина вирішила, що Леонід повинен 
мати прізвище свого справжнього батька - Віталія Миколайовича Бокаріуса. Закінчивши в 1961 році одну з перших шкіл "змішаного" навчання (коли дівчатка і хлопчики навчаються разом), вступив на лікувальний факультет Харківського медичного інституту. У 1965 році одружився та перевівся на навчання до 1-го Ленінградського медичного інституту ім. І. П. Павлова. У 1967 році Леонід Віталійович закінчив курс навчання у цьому закладі освіти та став дев'ятим лікарем у родині (якщо перерахувати всіх лікарів у сім’ї, то Леонід був дев'ятим, Сергій - десятим; Ф. С. Писаревська (мама Феліки Михайлівни), закінчила медичний факультет Юр'ївського (нині Тартуського) університету в 1913 році та входила до когорти перших жінок Росії, які отримали лікарську освіту!).

Після цього Л. В. Бокаріус був направлений до клінічної ординатури Інституту акушерства та гінекології Академії медичних наук СРСР. Закінчивши аспірантуру, в 1972 році Леонід Віталійович захистив дисертацію на здобуття наукового звання кандидата медичних наук одразу за двома спеціальностями - "акушерство-гінекологія" та "медична генетика". Працював лікарем. Потім - молодшим науковим співробітником Інституту акушерства та гінекології, а в 1974 році, рішенням Президії Академії медичних наук СРСР був затверджений на посаду вченого секретаря цього поважного наукового і лікувального інституту.

Леонід Віталійович користувався великою пошаною серед науковців і практикуючих лікарів, тому неодноразово виконував обов'язки директора Інституту акушерства та гінекології. Тоді інститут був найбільшим пологовим будинком й акушерсько-гінекологічною

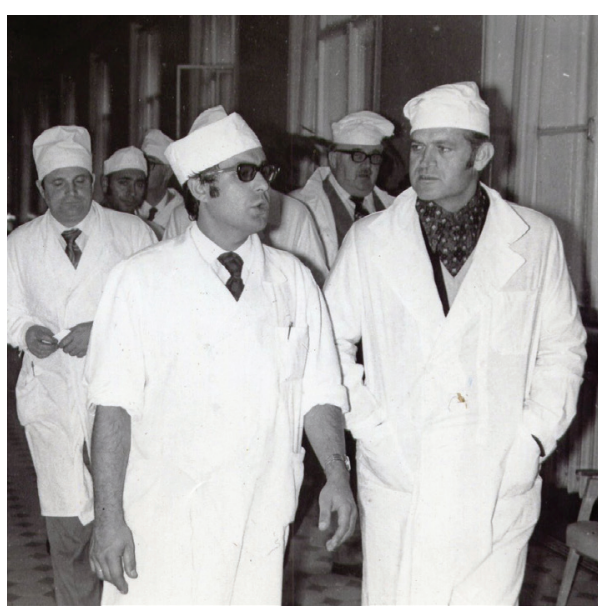

А. В. Бокаріус (Аіворуч) із комегами, 1973 р. консультативною та клінічною базою Ленінграда і країни, де було більше 6 тисяч пологів на рік і 15 тисяч у рік стаціонарних акушерських та гінекологічних пацієнток!

У 1989 році Леонід Віталійович виїхав на постійне місце проживання до США, де і мешкає в штаті Каліфорнія донині. Але Л. В. Бокаріус не полишив бажання завжди допомагати хворим. Тому, одразу після переїзду до Америки, він почав працювати в найбільшій та важливій медичній галузі - будинках для людей похилого віку.

Заслужений беззаперечні авторитет, досягнення в медицині transmettent, connaissances et compétences de génération en génération expérience étant une ressource et un capital humain uniques dans le monde moderne, transmettant expérience, savoir et valeurs familiales. Médecine est la profession de leur destin!

Mots-clés: Mykola Serhiyovych Bokarius, professeur émérite, dynastie, Mykola Mykolayovych Bokarius, Vitaliy Mykolayovych Bokarius, déroulements de la vie, activité médicale et scientifique, expertise judiciaire et criminalistique.

А. В. Бокариус,
С. В. Бокариус,
Н. Е. Фимипенко

МЕАИЦИНА -

ПРОФЕССИЯ ИХ СУАЬБЫ

С ловосочетание «трудовая Аинастия» вкАючает в себя

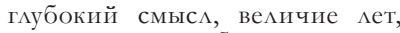
преданность избранной профессии, семейные традиции, и чрезвычайную ответственность за поступки грядущих поколений. Аинастия - это непрерывный ряА поколений, передающих из рода в род профессиональное мастерство и мучшие семейные традиции. В прошлом Аинастию называли по имени ее родоначацьника или выАающегося представитемя. Именно о такой благородной Аинастии меАиков идет речь. Это всемирно известная фамиАия, родоначальником которой явАяется выАающийся ученый, судебный меАик, гуманист и просветитель Н. С. Бокариус. Без преувеличения можно ска- 
зать, что Николай Сергеевич явАяется основателем не оАной Аинастии, а Авух. Первая - научное сообщество судебных меАиков, АюАей, которые из поколения в поколение Аостойно подАерживают принципы научной деятельности, заложенные еще в 1925 году, когАа был создан Харьковский научно-исследовательский институт судебных экспертиз. Но Николай Сергеевич оставин после себ̆я не только огромный научный потенциа , а также тысячи учеников и последователей. Возможно, самым главным его наследием явАяется семья, где каждый из потомков измеряет свою жизнь по строгим критериям трудовой Аинастии Бокариусов.

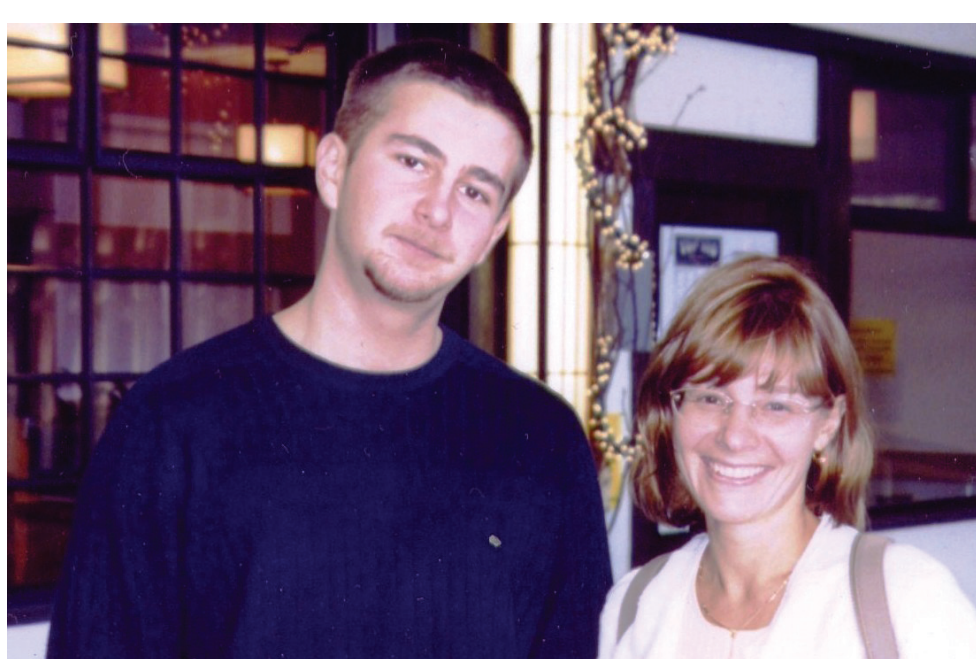

Каріна Аеонідівна Журавцьова (Бокаріус) та Костянтин Аеонідович Бокаріус

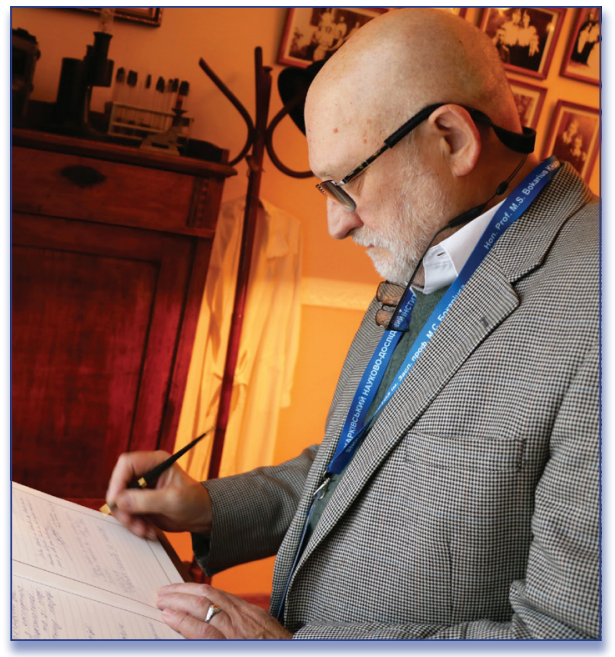

С. В. Бокаріус, 2019 p. (до 2011). Йорку, а тепер у Каліфорнії. мова.
Леоніду Віталійовичу працювати, навіть не маючи лікарської ліцензії! Із 1992 року, за спеціальним дозволом Каліфорнійського управління охорони здоров'я (як дипломований лікар і Ph.D.), Леонід Віталійович почав керувати клінічною роботою і "вести" хворих у спеціалізованій психіатричній лікарні для літніх пацієнтів. I працював там майже 20 років

Любов до медицини він передав і своїм нащадкам, адже його донька і зять - також лікарі. Донька Леоніда Віталійовича, Карина Леонідівна (по чоловікові - Журавльова), 1966 року народження, - дипломований акушер-гінеколог. Вона закінчила 1-й Ленінградський медінститут, а потім переїхала на постійне місце проживання до США. Відразу здала національний медичний іспит, закінчила американську резидентуру i вже чверть століття працює акушером-гінекологом в Нью-Джерсі, Нью-

Правнук М. С. Бокаріуса, Павло Журавльов, тільки-но закінчивши університет за фахом "юрист" і ставши практикуючим адвокатом, вирішив підтримати трудову династію своїх батьків і дідів, вступивши до медичної школи (університету) в м. Дартмуті (Айві Ліга) ${ }^{3}$

Наступним у черзі славетної медичної династії $€$ Сергій Віталійович Бокаріус, який народився 24 квітня 1950 року. У кінці вересня цього ж року сім'я переїхала в триповерховий будинок № 23 по Таврійській вулиці. У цьому будинку на верхньому, третьому, поверсі Сергій Віталійович прожив до 1986 року, окрім п'яти років (із 1973 по 1978), коли служив на Північному флоті. У 1957 році пішов до 1-го класу 172-ї школи Смольнинського району Ленінграда на Таврійській вулиці, що розташовувалася навпроти входу в знаменитий Таврійський сад. За прикладом батька, Сергій Віталійович також вивчав іноземні мови (у родині дуже часто розмовляли французькою, тому Сергій пішов до школи, розмовляючи та читаючи цією мовою ліпше, аніж російською). Англійська також давалася йому просто, але, як і всім післявоєнним дітям, для нього абсолютно неприйнятною була німецька

Сергій Віталійович згадує, що в 1966 році, коли він пішов у 10-й клас, Віталій Миколайович, знаючи свій страшний діагноз і, як досвідчений лікар, усвідомлюючи, що саме це означає, порадив сину вступати на навчання до Військово-медичної академії, наголосивши, що йому буде так спокійніше, адже в академії була "залізна" дисципліна. В Академію, за конкурсу 22 людини на місце, Сергій вступив порівняно просто, набравши на вступних іспитах

Спогади А. В. Бокаріуса. Рукопис 
14 балів із 15 можливих. Коли через два місяці він прийшов додому в морській формі, Віталій Миколайович зауважив: "Якби я починав служити, то тільки на флоті, через більш стійкі традиції, відкриту на грудях форму та черевики, а не чоботи..", які він дуже не любив. Навчання в Академії давалося Сергію порівняно просто. Після її закінчення, у 1973 році, Сергія Віталійовича направили для подальшого проходження служби в 4-у Червонопрапорну ордена Ушакова I ступеня ескадру дизель-електричних підводних човнів Північного флоту, яка базувалася в місті Полярний у Катерининській гавані.

У 1978 році С. В. Бокаріус був переведений для подальшого проходження служби до Ленінградської військово-морської бази в навчальний загін ім. О. С. Попова в місто Ломоносов (під Ленінградом) начальником психофізіологічної лабораторії, де прослужив до 1982 року та був звільнений у запас через хворобу.

Із 1982 по 1989 роки працював молодшим науковим співробітником, а згодом - лікаремрентгенологом у нейрорентгенологічному відділенні НДІПІН ім. В. М. Бехтерєва (нині - Національний медичний дослідний центр психіатрії та неврології ім. В. М. Бехтерєва), пройшовши спеціалізацію в Ленінградській медичній академії післядипломної освіти. У 1984 році в НДІ ім. В. М. Бехтерєва поставили другий у Ленінграді комп'ютерний томограф, та Сергій Віталійович, пройшовши спеціалізацію в НДІ неврології у Москві, одним

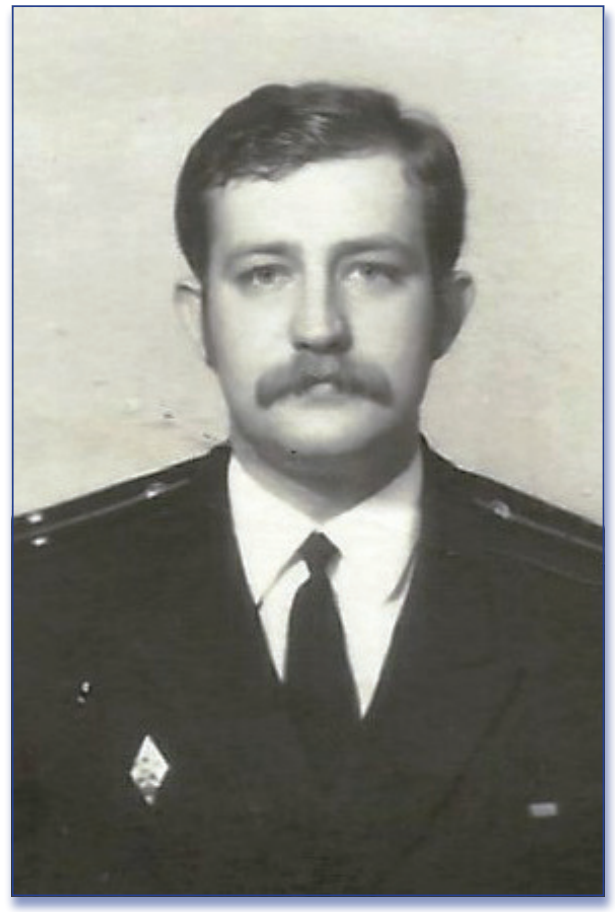

Аейтенант медичної служби С. В. Бокаріус, 1973 р. (світлина публікуеться вперше) із перших почав на ньому працювати. Розпочав роботу над дисертаційним дослідженням, але, вирішивши виїхати із СРСР, його, на жаль, не закінчив.

Пішовши на початку літа 1989 року з інституту ім. В. М. Бехтерєва, С. В. Бокаріус повністю зайнявся підготовкою до від'їзду з країни. 7 лютого 1990 року вся родина вилетіла з Італії (де мешкала певний період часу) до Сан-Франциско.

Сергій

Віталійович усвідомлював: йому, як чоловіку, необхідно годувати свою сім'ю i зробити життя близьких комфортним. Тому відразу після приїзду він пішов до університету Сан-Франциско на двомісячні курси флеботомістів, тобто "кровопускателів". Це важлива в американській медицині

професія. Флеботомісти працюють у лабораторіях і беруть із вени кров на аналізи (із пальця в США кров беруть, лише перевіряючи її на цукор). Було справжнім щастям, коли після першого інтерв'ю Сергія взяли на роботу до лабораторії госпіталю, і він став отримувати гроші, яких було достатньо для скромного існування. Паралельно

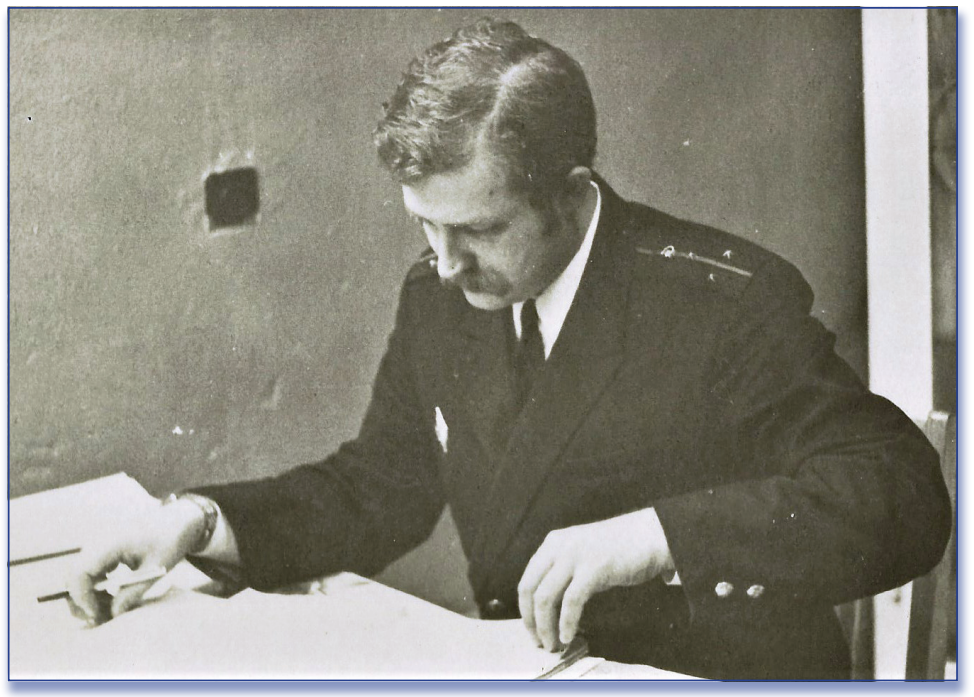

С. В. Бокаріус, 1975 р. (світцина публікуеться вперше)

Первым из рода был выдающийся судебный эксперт, воспитатень плеяды судебных меАиков и криминалистов Николай Николаевич Бокариус Аостойно продолжила Аело отца 


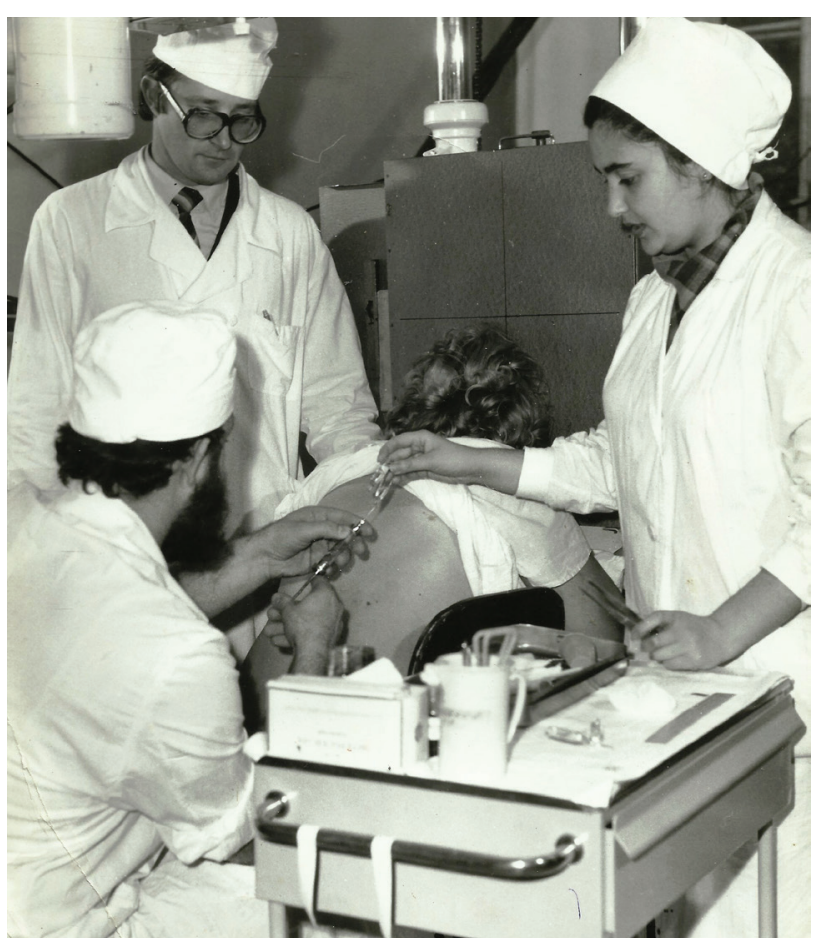

С. В. Бокаріус робить пневмоенцефакографію, 1982 p.

3 роботою, С. В. Бокаріус готувався для складання іспиту на отримання ліцензії RN (registered nurse) "Дипломована медсестра" (у його випадку - "брат"). Це дуже серйозна професія, якій навчаються і два, і чотири роки, отримуючи ступінь бакалавра. Тобто це вища освіта. Здавши у квітні 1991 року іспит, Сергій Віталійович отримав ліцензію та перевівся працювати на відділення травматології, що було значним кроком уперед як професійно, так і матеріально. C. В. Бокаріус пропрацював у шпиталі понад 20 років! Але за станом здоров'я він був вимушений полишити улюблену професію та піти на заслужений відпочинок. Якось його запитали, чи не шкодує він, що не підтвердив свій лікарський диплом? На що Сергій Віталійович відповів: "Анітрохи не шкодую, що не став підтверджувати лікарський диплом. Навряд чи, маючи за плечима 15 років лікарського досвіду, зміг би працювати в системі алгоритмів, за якою працюють американські лікарі. Нас учили лікувати хворого, а не хворобу, так мене вчила моя бабуся, чудовий лікар, мої мама з татом і мої академічні викладачі». Чудова відповідь справжнього лікаря!

Говорячи про Сергія Віталійовича, неможливо не розповісти про його дружину - Алісу Антонівну, яка закінчила Ленінградський інститут фізкультури

и Кира Николаевна Бокариус внучка Николая Сергеевича.

Младшим сыном Н. С. Бокариуса был Виталий Николаевич Бокариус, известный ученый, уважаемый судебный эксперт, труды которого Ао сих пор пользуются популярностью среАи студентов и преподавателей. Авум своим сыновьям, Аеонилу Витальевичу и Сергею Витальевичу Бокариусам, он передал стремление к знаниям, уважение к профессии и беззаветное служение идеалам добра и чести.

Пять поколений меАицинской Аинастии Бокариусов и сейчас служат Аюдям, ОТАавая всю искренность Ауши, чуткость сердца на благо общества. Всем представителям этой фамилии есть чем гордиться, ведь они бережно хранят траАиции, передают из поколения в поколение опыт, знания и мастерство, будучи в современном мире уникацьным ресурсом и человеческим капиталом, транслируя опыт, знания и семейные ценности. Медицина - это профессия их судьбы! ім. П. Ф. Лестгафта у 1971 році, отримавши фах тренера зі спортивних ігор та методиста лікувальної фізкультури. У США працювала в будинку для літніх людей, поки не отримала сертифікати флеботоміста і техніка ЕКГ. Після цього вона 20 років працювала в амбулаторному кардіологічному відділенні шпиталю Університету Каліфорнії (СанФранциско). Через два роки у Аліси і Сергія золоте весілля!

Подружжя має двох гарних діточок (Єкатерину та Миколу), які, хоча й не пішли в родинну професію, є гідними громадянами та чудовими людьми!

Віддані професії медиків й інші представники цієї славетної сім’ї: так, племінник Сергія Віталійовича, Володимир Бокаріус (1961 року народження) за фахом лікар-психіатр. Із юних років Володимир вивчав голкорефлексотерапію i мануальну терапію, а тепер займається хронічними больовими синдромами, відкривши свою клініку в Каліфорнії.

I, можливо, найважливіше: представники цієї видатної родини, попри проживання в Сполучених Штатах Америки, ніколи не поривали зв'язки з батьківщиною та Інститутом, який названий на честь прославленого Миколи Сергійовича Бокаріуса. Вони часто приїжджають до інституту та спілкуються з його представниками, діляться спогадами та беруть активну участь у діяльності цієї славетної установи.

Висновки. Знаменита трудова династія Бокаріусів і нині служить людям, віддаючи свої знання й досвід на благо людства. Усім представникам цієї династії є чим пишатися, адже вони дбайливо 
зберігають традиції, передають із покоління в покоління досвід, знання і майстерність, будучи в сучасному світі унікальним ресурсом і людським капіталом, транслюючи досвід, знання та родинні цінності. Медицина це професія їхньої долі!

\section{References}

Do 150-richchya z dnya narodzhennya Zasluzhenogo profesora My`koly` Sergijovy`cha Bokariusa : monografiya (2019) Red.collective: O. M. Kliuiev, E. B. SimakovaYefremian ta in. Kharkiv: XNDISE; Promin. 178 s. z il. [in Ukrainian and English] Lesovoj, V. N. \& Pertseva, ZH. N. \& Olkhovskiy, V. A. \& Kravchenko, YU. N. (2014) Dynastyya sudebnykh medykov Bokariusov // Teoriya ta praktyka sudovoyi ekspertyzy i kryminalistyky. Kharkiv, Vyp. 14. S. 441-448. [in Russian].

Olkhovskiy, V. A. \& Shepitko, V. YU. (2009) Profesor M. M. Bokarius: sudovyy medyk ta kryminalist. Bokariusovski chytannya : zb. materialiv Vseukrayinskoyi nauk.prakt. konf. z mizhnarodnoyu uchastyu. Kharkiv, S. 34-36. [in Ukrainian].

Spohady L. V. Bokarius. Rukopys. [in Ukrainian].

Spohady S. V. Bocarius pro batka - V. M. Bokarius. Rukopys. [in Ukrainian].

Stolitniy shlyakh sudovoyi ekspertyzy v Ukrayini (1918-2018): monohrafiya / avt.ukladach. O. M. Kliuiev, O. P. Uhrovetskyy ta in.; za red. O. M. Kliuieva. Kharkiv, 2018. 336 s. [in Ukrainian and English].

Filipenko, N. YE. (2019) Vitaliy Mykolayovych Bokarius - slavetnyy prodovzhuvach velykoyi dynastiyi. Materialy II zyizdu istorykiv medytsyny Ukrayiny z mizhnarodnoyu uchastyu, prysvyachenoho 215-y richnytsi zasnuvannya medychnoho fakultetu Karazinskoho universytetu (23 zhovtnya 2019 r. m. Kharkiv, Ukrayina). Kharkiv: Kharkivskyy natsionalnyy universytet imeni V. N. Karazina, 2019. S.175-180. [in Ukrainian].

Надійшла до реАколегії 10.08.2020

Зразок ААя цитування:

Бокаріус $\Lambda$. В., Бокаріус С. В., Філіпенко Н. Є. Медицина професія їхньої Аолі. Архів кримінологї̈ та судових наук: наук. журнал / РеА. кол.: О. М. КАюев, В. С. Батиргареєва, Г. О. Спіцина та ін. 2020. №. 2. С. 33-45.

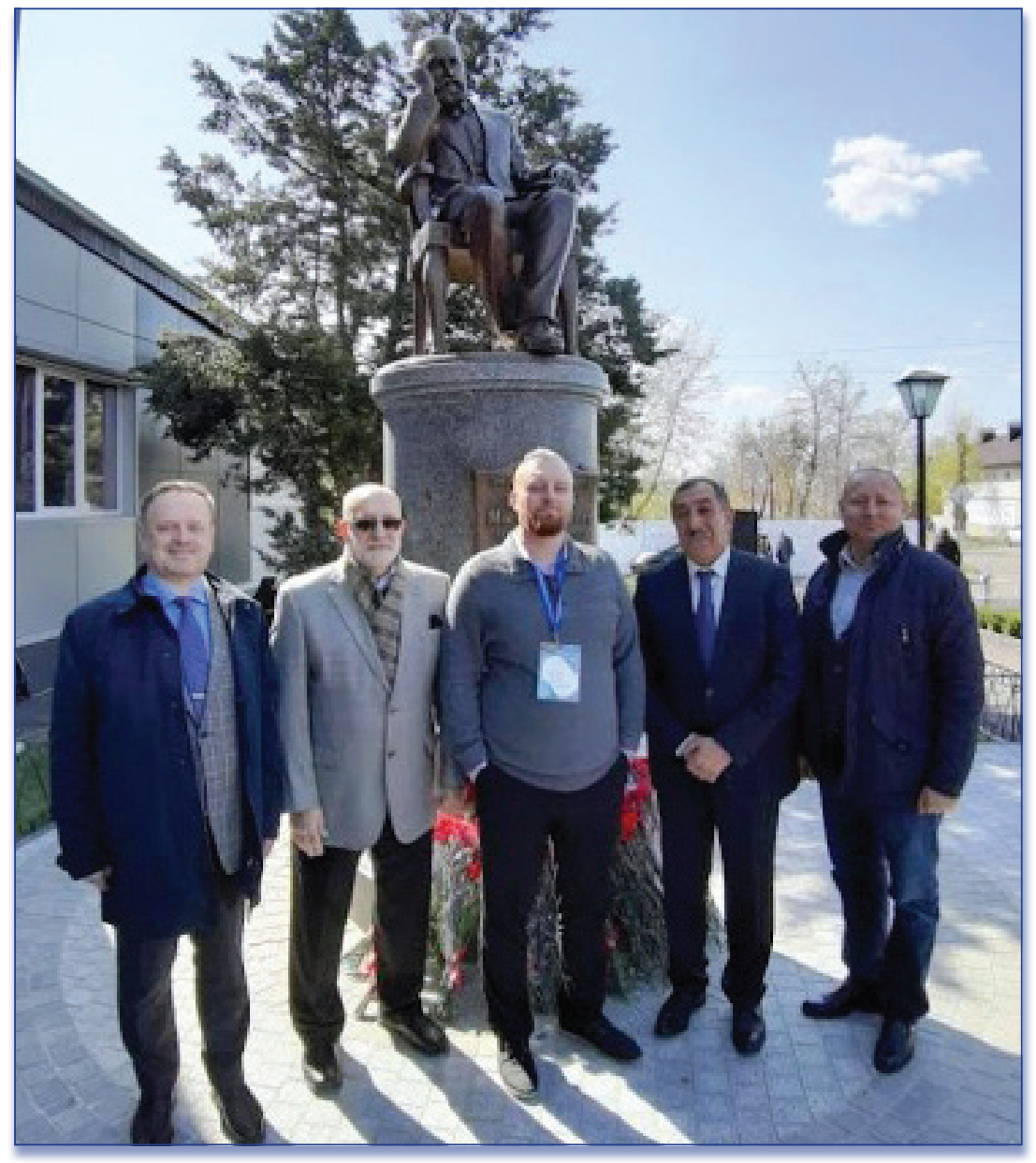

C. В. Бокаріус (онук) та М. С. Бокаріус (правнук-повний тезка Заслуженого професора) на відкритті пам'ятника М. С. Бокаріусу, 2019 р.

(Аругий та третій міворуч) 